\title{
A CENSURA NO BANCO DOS RÉUS: JULGADOS DOS TRIBUNAIS SUPERIORES NA DITADURA MILITAR
}

Lucas Borges Carvalho ${ }^{1}$

\section{Resumo}

O artigo analisa as principais decisões proferidas pelo Supremo Tribunal Federal e pelo Tribunal Federal de Recursos em casos envolvendo a censura de espetáculos e diversões públicas, tal como imposta na ditadura militar (1964-1985). Argumenta-se que a censura foi legitimada pelas decisões dos tribunais, na medida em que estas atribuíram ampla discricionariedade às autoridades administrativas para controlar as expressões culturais, sempre com o objetivo de proteger a moral pública e os próprios cidadãos. Essa posição - amparada em três elementos centrais: a teoria clássica da discricionariedade administrativa, o paternalismo e a noção de autoridade - foi revista em meados da década de 1980, durante a transição para o regime democrático, quando os tribunais passaram a defender o princípio da autonomia dos cidadãos e a imposição de limites jurídicos à atuação das autoridades administrativas.

Palavras-chave: Censura; Liberdade de Expressão; Ditadura Militar; Autoritarismo; Democracia.

\section{INTRODUÇÃO}

A história dos tribunais no Brasil não é a história da democracia, nem a da liberdade. Sem dúvida, seguindo as vicissitudes e os percalços da vida política nacional, é possível identificar, no âmbito do poder judiciário, inúmeros acontecimentos marcados pela instabilidade institucional, pela deferência à autoridade e pela chancela de práticas repressivas.

Neste artigo, pretende-se contar um pequeno, mas relevante capítulo dessa história. Como ponto de partida, apresenta-se a seguinte questão: como se posicionaram o Supremo Tribunal Federal (STF) e o Tribunal Federal de Recursos (TFR) no julgamento de casos envolvendo a censura de espetáculos e diversões públicas, no período da ditadura militar (1964-1985) ?²

O objetivo geral, portanto, é compreender e identificar os fundamentos jurídicos da censura de diversões públicas, a partir da análise da jurisprudência dos tribunais superiores. Como objetivo específico, propõe-se, ainda,

\footnotetext{
${ }^{1}$ Doutor em Direito (Universidade de Brasília - UnB). Procurador Federal, Brasília - DF. E-mail: lucasbcarvalho@gmail.com

${ }^{2}$ As decisões do STF aqui referidas podem ser encontradas, na íntegra, no sítio do tribunal na internet. Quanto aos acórdãos do TFR, é possível ter acesso às ementas dos julgados proferidos a partir de 1980, no sítio do Superior Tribunal de Justiça - STJ. A íntegra desses e de acórdãos mais antigos pode ser solicitada ao Arquivo Geral do STJ, ao qual agradeço por ter disponibilizado o acesso à parte dos acórdãos citados neste artigo. Outros julgados foram localizados na Revista de Jurisprudência do TFR, bem
} 
investigar as principais normas e as interpretações doutrinárias em vigor à época.

A abordagem proposta se justifica na medida em que a narrativa judicial é sempre estruturada em torno de um conflito, no caso em questão, entre, de um lado, a autoridade estatal e a repressão e, de outro, autores, produtores ou editoras atuando em defesa da liberdade. A ideia de autoridade aqui está vinculada à proteção de um passado que deve permanecer intocável ou, ainda, à defesa da obediência, da tradição e das hierarquias sociais. Por sua vez, a noção de liberdade se associa com a constituição de um espaço público compartilhado, no qual a ação humana pode se apresentar de forma autônoma, enquanto faculdade de começar algo novo e imprevisível e que, por isso mesmo, se opõe a crenças e a padrões morais e sociais estabelecidos (ARENDT, 2011, p. 213-220).

Nesse sentido, importa considerar que, no bojo de um processo, as partes devem apresentar argumentos, que se traduzam em termos jurídicos, a fim de sustentar as suas respectivas interpretações do direito e da realidade social subjacente. Isso levou, no contexto da ditadura militar, a que a defesa da liberdade de expressão se amparasse, paradoxalmente, nas normas de exceção então em vigor ou, ainda, que a censura tivesse que ser admitida e sustentada, abertamente, pelas autoridades públicas.

Os próprios tribunais não decidem de forma homogênea. Mesmo em um período de exceção, há votos dissidentes, que conferem voz e representatividade a uma posição então minoritária. Ademais, longe de seguir uma linha rígida de coerência, o tribunal pode rever ou se afastar de um princípio consagrado em um precedente, seja para cassar a liberdade, seja para chancelar a repressão. Sendo assim, uma decisão judicial ou, de forma mais precisa, um conjunto de decisões judiciais é sempre o registro e o produto de um embate entre visões de mundo dissonantes, o que nos permite rever o passado a partir de pontos de vista mais abrangentes e plurais.

Postos esses termos, pretende-se demonstrar que, de forma geral, os tribunais superiores chancelaram a censura de diversões públicas, atribuindo às autoridades ampla margem decisória no exercício do controle sobre as obras culturais, sempre com o objetivo de proteger a tradição, a moral pública e os próprios cidadãos dos efeitos nocivos decorrentes dessas obras. Essa posição - amparada em três elementos centrais: a teoria clássica da discricionariedade administrativa, o paternalismo e a noção de autoridade - somente começou a ser revista em meados da década de 1980, no período de transição para o regime democrático, quando os tribunais passaram a acolher argumentos que defendiam a autonomia dos cidadãos e a imposição de limites jurídicos à atuação das autoridades administrativas.

É nesse confronto entre autoridade e liberdade, que se constitui a história narrada nesse artigo: a história da censura e a correlata história dos tribunais brasileiros. É certo que, como mencionado, essa não é uma narrativa da liberdade, nem da democracia. Seria exagero, porém, descrevê-la como uma imposição irrestrita, sem conflito,

como a partir de referências a decisões na historiografia sobre o assunto e nas próprias decisões judiciais, quando mencionavam precedentes. 
sem resistências e sem algumas derrotas, de uma prática institucional repressiva. Para o bem ou para o mal, a história é sempre algo mais do que qualquer visão simplória e maniqueísta pode querer afirmar.

\section{A CENSURA DE DIVERSÕES PÚBLICAS: ASPECTOS JURÍDICOS}

A censura de diversões públicas visava proteger a moral pública e os bons costumes, exercendo o controle sobre o teatro, o cinema, a música e a programação de entretenimento do rádio e da TV, como as novelas e os programas de auditório. Era legalizada, imposta por um corpo técnico-burocrático especializado, que seguia ritos e procedimentos formais, dentre os quais se encontrava a necessidade de elaboração de pareceres que expunham as justificativas para a proibição ou qualquer espécie de "corte" nas obras analisadas.

A Emenda Constitucional no 01/1969, reproduzindo norma similar constante das Cartas de 1934 (art. 113, item 9), 1946 (art. 141, \$ 50) e 1967 (art. 150, \$ 8º), conferia amparo constitucional à censura de diversões públicas, conforme se depreende do disposto em seu art. 153, $\$ 8^{\circ}$ :

Art. 153. [...]

\ $8^{\circ}$ É livre a manifestação de pensamento, de convicção política ou filosófica, bem como a prestação de informação independentemente de censura, salvo quanto a diversões e espetáculos públicos, respondendo cada um, nos têrmos da lei, pelos abusos que cometer. É assegurado o direito de resposta. A publicação de livros, jornais e periódicos não depende de licença da autoridade. Não serão, porém, toleradas a propaganda de guerra, de subversão a ordem ou preconceitos de religião, de raça ou de classe, e as publicações e exteriorizações contrárias à moral e aos bons costumes.

A interpretação desse dispositivo constitucional foi objeto de forte controvérsia. De um lado, uma leitura mais liberal sustentava que a censura prévia somente poderia ser admitida quanto aos espetáculos e diversões públicas, não abrangendo livros, jornais e periódicos. Estes estariam protegidos da censura prévia, já que, para esses casos, a Constituição, expressamente, dispensava a "licença da autoridade". ${ }^{3}$ Por isso mesmo, as exceções referidas na parte final do artigo autorizariam apenas a punição - ou qualquer outro tipo de interferência estatal - somente após efetuada a publicação. Era essa a interpretação defendida por Pontes de Miranda:

Na parte final do texto, há permissão de leis que punam a propaganda de guerra e de processos violentos para se subverter a ordem pública ou a ordem social, de preconceitos étnicos ou de classe: não, porém, a censura dos livros, revistas, jornais, etc. A censura (précensura) só se permite se se trata de espetáculos e diversões públicas - isto é, não se conhece censura de livros, revistas, diários e outros periódicos (MIRANDA, 1973, p. 160).

Em sentido contrário, uma leitura mais autoritária defendia que o texto constitucional não havia feito nenhum tipo de distinção ao considerar "intoleráveis" determinados conteúdos, de maneira que pouco importaria o meio de divulgação: exercer a censura prévia constituiria uma forma legítima e necessária de atribuir eficácia à

\footnotetext{
${ }^{3}$ Tal espécie de licença era condição necessária no período do Estado Novo, cabendo ao Departamento de Imprensa e Propaganda - DIP exercer esse controle. Como lembra Smith: "de fato, a partir de 1940, o DIP recusou registro a 420 jornais e 346 revistas. Método de controle semelhante era a licença para importar papel de imprensa, outra atividade sujeita ao DIP. Sessenta e um jornais e revistas tiveram de suspender sua publicação simplesmente por falta de acesso ao papel” (SMITH, 2000, p. 25).
} 
Constituição, evitando-se que uma mensagem ou um discurso "não tolerado" viesse a público. É o que sustentava Alfredo Buzaid:

Logo, dizer que só estão sujeitas a censura as diversões e os espetáculos públicos significa
limitar o controle do Estado justamente no ponto em que o legislador o ampliou e reduzir a
uma exceção onde a Constituição expressamente estabeleceu duas. [...] O legislador
constituinte, ao regular as duas matérias, foi lógico e coerente, porque não teria sentido
fiscalizar previamente diversões e espetáculos públicos e permitir que medrassem livremente
publicações pornográficas. Quanto a estas não se limitou a simples controle. Declarou-as
intoleráveis. Em ambos os casos, a verificação prévia é legítima, porque o Estado tem o
poder-dever de velar pela moralidade pública e formação sadia da juventude (BUZAID,
1970, p. 33).

Essa divergência, em torno de qual a interpretação mais adequada das normas constitucionais então vigentes, encontra-se no cerne de toda a discussão sobre a legalidade da censura de diversões públicas, refletindose tanto na legislação quanto nos conflitos submetidos ao judiciário.

No âmbito da legislação infraconstitucional, verifica-se que os diversos diplomas legais convergiam no sentido de autorizar, de forma ampla e discricionária, a realização de censura prévia nas hipóteses excepcionais referidas no art. 153, $\$ 8^{\circ}$, da Emenda Constitucional no 01/1969. Assim, a princípio, a legislação não acatou a distinção proposta por Pontes de Miranda, de modo que tanto as diversões e espetáculos públicos quanto as publicações impressas, no que concerne aos aspectos relativos à moral e aos bons costumes, poderiam ser, do ponto de vista jurídico, submetidas à censura prévia. É o que se depreende do disposto nas duas principais normas que regulavam a censura de diversões públicas: o Decreto no 20.493, de 24 de janeiro de 1946, e o Decreto-lei nº 1.077, de 26 de janeiro de 1970.

O primeiro ato foi promulgado durante a vigência da Constituição de 1937, após o fim do Estado Novo e pouco antes da promulgação da Constituição de $1946 .{ }^{4}$ O Decreto atribuía ao Serviço de Censura de Diversões Públicas, o SCDP (posteriormente, Divisão de Censura e Diversões Públicas - DCDP), órgão de natureza policial e vinculado ao Ministério da Justiça, competência para censurar, total ou parcialmente, as expressões culturais. De acordo com Kushnir,

[...] foi esse Decreto que justificou a maioria dos pareceres dos censores, tanto para autorizar como para vetar, até 1988 . Enorme e tentacular, era capaz de dar conta de cada diferente veto. Todos os censores que entrevistei o sabiam de cor e o citavam no artigo ou parágrafo adequado a cada situação. Difícil é lidar com o fato de que, feito em um período de redemocratização, justificou proibições ditatoriais (KUSHNIR, 2004, p. 101).

Com efeito, o Decreto trazia normas específicas para o controle sobre filmes, peças de teatro, cartazes e anúncios de filmes e espetáculos, bem como de discos, de desfiles de carnaval e para a transmissão e exibição

\footnotetext{
4 "O Decreto 20.493 foi assinado em 24 de janeiro de 1946, ainda no mandato tampão de José Linhares, exatamente uma semana antes da posse de Eurico Gaspar Dutra e da instalação da constituinte” (VIEIRA, 2010, p. 22). Vale ressaltar que a Constituição de 1937 (art. 122, item 15, alíneas a e b) continha expressa autorização para que fosse estabelecida, por lei, "a censura prévia da imprensa, do teatro, do cinematógrafo, da radiodifusão, facultando à autoridade competente proibir a circulação, a difusão ou a representação", assim como "medidas para impedir as manifestações contrárias à moralidade pública e aos bons costumes".
} 
radiotelefônica, atribuindo largas competências às autoridades administrativas para exercer a censura prévia sobre essas e outras expressões culturais. Prevaleciam, ademais, normas de conteúdo aberto e indeterminado, tais como "decoro público", "maus costumes", "ordem pública”, "dignidade ou interesse nacionais" e "linguagem imprópria à boa educação do povo" (arts. 41 e 77).

Com isso, ainda que de forma incipiente, o Decreto no 20.493/1946 consagrava os três pilares jurídicos fundamentais da censura de diversões públicas, todos acolhidos e mais bem desenvolvidos no âmbito jurisprudencial, conforme veremos mais adiante. São eles: (i) a teoria clássica da discricionariedade administrativa, segundo a qual as autoridades competentes detêm a prerrogativa de tomar decisões sem vinculação a padrões jurídicos mandatórios e sem efetivo controle do poder judiciário sobre o mérito dos atos administrativos; ${ }^{5}$ (ii) $o$ paternalismo, concepção que atribui ao Estado um forte papel de tutela sobre os cidadãos, os quais são concebidos como pessoas vulneráveis que demandam proteção diante dos efeitos nocivos gerados pelos conteúdos divulgados pelos meios de comunicação; e (iii) o princípio da autoridade, que reforça os dois anteriores, na medida em que sustenta uma estrutura social hierárquica, exigindo obediência incondicional às determinações estatais e às tradições morais.

Com o advento do Decreto-lei no 1.077/1970 essas normas e esses princípios jurídicos ganharam ainda maior amplitude. Logo em seu art. $1^{\circ}$, consagrando a interpretação de Alfredo Buzaid a respeito do disposto na EC nº 01/1969, a norma estabelecia que não seriam toleradas publicações e exteriorizações contrárias à moral e aos bons costumes, independentemente dos meios de comunicação utilizados, o que incluía as diversões públicas, a programação da TV e do rádio e as publicações impressas. Especificamente em relação a estas, os artigos $2^{\circ}$ e $3^{\circ}$ autorizavam a "verificação prévia", pelos órgãos do Ministério da Justiça, de livros e periódicos, podendo ser vedada a "divulgação da publicação" ou "a busca e a apreensão de todos os seus exemplares". A justificava para a edição do ato, conforme mencionado em seus consideranda, referia-se à proteção da "instituição da família" e de seus "valores éticos" em face de publicações e canais de televisão que "estimulam a licença, insinuam o amor livre e ameaçam destruir os valores morais da sociedade brasileira" em obediência a "um plano subversivo, que põe em risco a segurança nacional" (Decreto-Lei no 1.077/1970).

Diante da controvérsia a respeito da correta interpretação do texto constitucional, pode-se dizer que o Decreto-lei no 1.077/1970 foi promulgado com o propósito de sepultar a discussão e conferir legalidade à prática

\footnotetext{
${ }^{5} \mathrm{Na}$ explicação de Hely Lopes Meirelles: "em tais casos [nos atos vinculados] a conduta do administrador se confunde com a do juiz na aplicação da lei, diversamente do que ocorre nos atos discricionários em que, além dos elementos sempre vinculados (competência, finalidade e forma), outros existem (motivo e objeto), em relação aos quais a Administração decide livremente, e sem a possibilidade de correção judicial, salvo quando o seu proceder caracterizar excesso ou desvio de poder. Em tais atos (discricionários), desde que a lei confia à Administração a escolha e valoração dos motivos e do objeto, não cabe ao Judiciário rever os critérios adotados pelo administrador, porque não há padrões de legalidade para aferir essa atuação" (MEIRELLES, 1976, p. 123). Em suma, seguindo Gustavo Binenbojm, pode-se dizer que a atribuição de um "espaço livre de decisão ao administrador" se encontra no cerne da teoria clássica da discricionariedade administrativa (BINENBOJM, 2008, p. 39).
} 
da censura prévia, estendendo-a para além do âmbito tradicional da censura de diversões públicas, de modo a abranger também os jornais, os periódicos e a programação do rádio e da TV, no que concerne aos aspectos relativos à moralidade pública e aos bons costumes.

\section{O DEBATE NOS TRIBUNAIS SUPERIORES: CONSTRUÇÃO, CONSOLIDAÇÃO E REVISÃO DA JURISPRUDÊNCIA}

\section{Contestações ao Decreto-lei nº 1.077/1970}

No mesmo ano de sua publicação, a constitucionalidade do Decreto-lei no 1.077/1970 foi alvo de representação encaminhada pelo partido Movimento Democrático Brasileiro (MDB) ao Procurador-Geral da República, único legitimado a suscitar a inconstitucionalidade de lei ou ato normativo em tese, segundo as normas vigentes à época. O Procurador-Geral, no entanto, entendeu por bem arquivar o pedido, ao invés de encaminhá-lo à apreciação do Supremo Tribunal Federal.

Com o objetivo de reverter essa decisão, o partido ingressou com uma Reclamação no STF. Ao julgar o caso, em março de 1971, o tribunal emitiu uma decisão de natureza formal, sem se manifestar sobre o mérito da demanda. Prevaleceu o entendimento, fundado no disposto no art. 119, I, l, da EC no 01/1969, ${ }^{6}$ de que a representação era ato privativo do Procurador-Geral da República, cabendo a este, discricionariamente, avaliar a pertinência de seu encaminhamento ao STF. Os Ministros consideraram, ainda, a possibilidade de qualquer interessado recorrer ao judiciário e, diante de um caso concreto, pleitear a declaração incidental de inconstitucionalidade do ato normativo em questão (BRASIL, STF, 1971).

O único voto dissidente foi o do Ministro Adauto Cardoso - que renunciou ao cargo após esse julgamento, sendo o advogado, tempos depois, de casos importantes contra a censura. ${ }^{7} \mathrm{O}$ Ministro se baseou no disposto no art. 2º da Lei no 4.337/1964 e no art. 174, \$ 1º, do Regimento Interno do STF, para sustentar que o ordenamento jurídico atribuiu ao Procurador-Geral da República o dever de encaminhar a representação ao STF

\footnotetext{
${ }^{6}$ Art. 119. Compete ao Supremo Tribunal Federal: I - processar e julgar originariamente: [...] 1) a representação do ProcuradorGeral da República, por inconstitucionalidade de lei ou ato normativo federal ou estadual. A redação era a mesma na Constituição de 1967 (art. 114, I, I).

${ }^{7}$ Conforme noticiou O Estado de São Paulo (1971), na edição do dia 11 de março de 1971, dia seguinte ao julgamento: "o presidente Baleeiro lia a decisão do tribunal, determinando o arquivamento do pedido do MDB, quando Adauto Cardoso o aparteou: 'sinto que, com esta solidão em que me coloquei, mais sobreleva a incapacidade em que me encontro para defender alguma coisa por cujo resguardo eu pretendia pugnar nesta Casa. Creio que, com a resolução de agora, a ação direta de declaração de inconstitucionalidade está morta. [...] E este [o Procurador-Geral da República] se tornou o senhor de julgar, antes do Supremo Tribunal, e com exclusão dele, da procedência da representação. Isto equivale a tornar o Poder Executivo juiz da inconstitucionalidade das leis'. Em seguida, Adauto Cardoso levantou-se, puxou os punhos da camisa para fora do paletó e despiu a toga por cima da cabeça, consumando simbolicamente a sua renúncia." Vale ressaltar que, antes de ser Ministro do STF, Adauto Cardoso exerceu diversos cargos políticos, sendo um dos fundadores da União Democrática Nacional (UDN). Posteriormente, apoiou o golpe de 1964, filiando-se à Aliança Renovadora Nacional (ARENA). Cf. GRINBERG, 2002.
} 
no prazo de trinta dias, ainda que dela discordasse. ${ }^{8}$

Conforme essa leitura, a competência para a decisão sobre a constitucionalidade de uma lei ou ato normativo era do tribunal e não do Procurador-Geral da República, de maneira que este, ao determinar o arquivamento da representação do MDB, teria usurpado a competência da Corte. Em suas palavras,

O nobre Dr. Procurador apreciou desde logo a representação, não para encaminhá-la, com parecer desfavorável, como lhe faculta o Regimento, mas para negar-lhe a tramitação marcada na lei e na nossa Carta Interna. Com isso, ele se substituiu ao Tribunal e declarou, ele próprio, a constitucionalidade do Dl. 1.077-70 (BRASIL, STF, 1971, p. 349).

O Ministro também suscitou a relevância política da questão, seja no que concerne ao tema da censura propriamente dito, seja quanto ao fato de que, dificilmente, particulares apresentariam demandas como aquela, tendo em vista a possibilidade concreta de sofrer represálias. É o que se depreende da seguinte passagem de seu voto:

[...] de janeiro de 1970 até hoje, não surgiu, e certamente nem surgirá, ninguém, a não ser o Partido Político da Oposição, que a duras penas cumpre o seu papel, a não ser ele, que se abalance a arguir a inconstitucionalidade do decreto-lei que estabelece a censura prévia (BRASIL, STF, 1971, p. 348).

Como se pode observar, o tribunal acatou um argumento de ordem formal e não avaliou a constitucionalidade do Decreto-Lei no 1.077/1970, um dos diplomas normativos mais importantes da repressão à livre manifestação do pensamento, fato que, em última instância, contribuiu para chancelar e legitimar a prática repressiva da censura. Prevaleceu, ainda, uma leitura restrita do controle de constitucionalidade abstrato, a qual, na prática, atribuía ao Procurador-Geral da República - autoridade, à época, nomeada livremente pelo Presidente da República - grande poder para "filtrar" e impedir que determinadas controvérsias constitucionais fossem submetidas a julgamento pelo STF. Em suma, pode-se dizer que essa decisão assegurou às autoridades administrativas mais poderes para instituir, com ampla discricionariedade, restrições à liberdade de expressão. ${ }^{9}$

Dois anos após o julgamento da Reclamação no 849 pelo STF, foi a vez do Tribunal Federal de Recursos

\footnotetext{
${ }^{8}$ A redação desses dispositivos legais, conforme citada no acórdão (BRASIL, STF, 1971), é a seguinte: Lei no 4.337/1964: art. 2 Se o conhecimento da inconstitucionalidade resultar de representação que lhe seja dirigida por qualquer interessado, o ProcuradorGeral da República terá o prazo de 30 (trinta) dias, a contar do recebimento da representação, para apresentar a arguição perante o Supremo Tribunal Federal. Regimento Interno STF: Art. 174, $\$ 1$ 1 . Provocado por autoridade ou por terceiro para exercitar a iniciativa prevista neste artigo, o Procurador-Geral, entendendo improcedente a fundamentação da súplica, poderá encaminhá-la com parecer contrário.

${ }^{9}$ Este foi o acórdão mais relevante em torno da censura de diversões públicas levado ao conhecimento do STF naquele período, cabendo registrar que a grande maioria das demais decisões se circunscreve a questões de conflito de competência entre os Estados e a União. Tal conflito ocorria, especialmente, porque a Constituição de 1946 era omissa a respeito do assunto, o que foi resolvido com o advento da Constituição de 1967 (art. 8º, VII, d) que atribuiu à União o poder de censurar as diversões públicas, dispositivo reproduzido na EC no 01/1969 (art. 80, VIII, d). A esse respeito, ver os acórdãos proferidos no ROMS no 14.685, julgado em 17.8.1966 e no RE 68.396, julgado em 28.9.1971. Sobre a questão, assim argumentava o Ministro Aliomar Baleeiro em voto proferido no RMS no 18.534/1968: "ainda não há, na jurisprudência do STF, standards claros e seguros a respeito da linha divisória entre o obsceno ou o pornográfico, dum lado, e o publicável do outro lado, porque relativamente poucos os casos trazidos à sua barra. Os recentes acórdãos sobre filmes nacionais envolviam mais questões de competência da União e dos Estados para o exercício da censura, que, num deles, era antes um pretexto para cobrança de taxas" (BRASIL, STF, 1968, p. 1.180).
} 
ser instado a se manifestar sobre a constitucionalidade do Decreto-Lei no 1.077/1970. O mandado de segurança foi impetrado pela Editora Civilização Brasileira contra ato do Ministro da Justiça que havia proibido a publicação, circulação e venda da 2a edição do livro Último Tango em Paris, de Robert Alley (BRASIL, TFR, 1973).

A impetrante suscitou a inconstitucionalidade do Decreto-Lei no 1.077/1970, alegando que: (a) o ato impugnado constituía abuso de poder, visto atentar contra a livre manifestação do pensamento; (b) a Constituição autorizava a censura prévia, desde que fundamentada e apenas sobre os espetáculos e diversões públicas, sendo expressa a respeito da desnecessidade de licença para a publicação de livros; (c) a restrição a qualquer publicação somente poderia ser efetuada a posteriori, nas hipóteses do art. 153, \$ 8º da EC nº 01/1969.

Por unanimidade, o TFR julgou a ação improcedente, sob o argumento de que o livro se enquadrava na exceção prevista na parte final do $₫ 8^{\circ}$ do art. 153 da EC nº $01 / 1969$, visto que atentava contra a moral e os bons costumes. Nesse sentido, ao conferir competência ao Ministro da Justiça para proibir a divulgação ou determinar a apreensão de publicação nesses casos, o Decreto-Lei no 1.077/1970 apenas pôs em execução o que já previa a Carta de 1969. Conforme assentado na ementa do acórdão:

A Constituição (art. 153, $\$ 8^{\circ}$ ) não tolera publicações e exteriorizações contrárias à moral e aos bons costumes, colocando-as em pé de igualdade com a propaganda de guerra, de subversão da ordem ou de preceitos de religião, de raça ou de classe. O Decreto-lei no 1.077, de 1970, quando dispõe sobre a intolerabilidade e a apreensão de publicações contrárias à moral e aos bons costumes, não restringe direito nem faculdade prevista na Constituição, cujo pensamento reproduz. É mero instrumento para a execução do preceito de maior hierarquia. [...] Segurança denegada (BRASIL, TFR, 1973, p. 58).

Assim, nos dois casos, o STF e o TFR avalizaram o conteúdo do Decreto-lei no 1.077/1970, reafirmando, na linha da interpretação defendida por Alfredo Buzaid, a constitucionalidade da realização de censura prévia não só em relação às diversões públicas, mas, também, no que concerne à publicação de livros e periódicos, quando o seu conteúdo atentasse contra a moral e os bons costumes. Anote-se, ainda, que ambos os julgados consagraram uma concepção paternalista, ao atribuir às instituições estatais o dever de proteger os cidadãos e as tradições morais em face, conforme as palavras do Ministro do TFR, Moacir Catunda, do "niilismo da publicação", a qual, aliás, havia deixado "estarrecido" o Ministro Peçanha Martins. ${ }^{10}$

\section{Apreensão de periódicos com base na Lei de Imprensa (Lei no 5.250/1967)}

A Lei de Imprensa, Lei no 5.250, de 9 de fevereiro de 1967, também previa a possibilidade de apreensão de impressos subversivos ou ofensivos à moral e aos bons costumes. No entanto, a competência para determinar

\footnotetext{
${ }^{10}$ Segundo o Ministro Moacir Catunda: "a portaria ministerial autorizativa da apreensão, representa o desfecho do processo administrativo que concluiu porque o Último Tango em Paris traduz nilismo, em matéria de literatura, perniciosa aos padrões morais comuns, e aos bons costumes, desprocedendo, desse modo, a alegação de que será produto de puro arbítrio". Na mesma linha, o Ministro Peçanha Martins afirmou o seguinte: "não conheço o livro. Mas tive oportunidade de ler algumas das suas
} 
tal apreensão era atribuída ao poder judiciário e, excepcionalmente, em casos de urgência, ao Ministro da Justiça. Nesta hipótese, de acordo com a redação original da lei, o ato administrativo deveria ser submetido, no prazo de cinco dias, à aprovação do Tribunal Federal de Recursos, órgão ao qual caberia a palavra final sobre a legalidade da apreensão (art. 63, $\left.\$ \$ \$ 1^{\circ} \mathrm{a} 4^{\circ}\right)$.

Essa necessidade de submissão do ato ao poder judiciário foi revogada pelo Decreto-Lei no 510, de 20 de março de 1969. Após essa data, portanto, o Ministro da Justiça ficou autorizado, nas situações de urgência e independentemente de qualquer autorização ou ratificação judicial, a determinar a apreensão de jornais, livros e revistas, a fim de evitar a divulgação de propaganda de guerra, preconceito de raça ou classe, subversão da ordem ou atentado à moral e aos bons costumes.

Com base nesse ato normativo, o Ministro da Justiça determinou a apreensão de diversos periódicos, entre eles, (i) o jornal mensal "EX", sob a justificativa de que a publicação afrontava a moral pública e os bons costumes; (ii) o jornal "Jerusalém", sob a justificativa de que a publicação continha propaganda de preconceito de raça, consubstanciada na divulgação tendenciosa de "torturas e baixas sofridas pelos palestinos, com intuito de estimular o ódio contra os judeus" (BRASIL, TFR, 1983a, p. 184); e, por fim, (iii) o diário "Luta - O Jornal do Povo", que apresentava noticiário "tendencioso", valendo-se de "linguagem imprópria e rasteira", conforme, por exemplo, a manchete do jornal, da edição de 08/12/1982: "Quis dar uma de machão e sifu... Lutou pela xota e levou um tiro na bunda. Era Gay" (BRASIL, TFR, 1983b, p. 145).

De forma geral, os impetrantes questionavam a competência do Ministro da Justiça, alegando falta de fundamentação do ato e violação ao direito de defesa. Ademais, a apreensão somente poderia ser admitida em hipóteses excepcionais, nomeadamente, por ordem judicial ou, em caso de urgência, por determinação do Ministro da Justiça (Lei no 5.250/1967, art. 61, $\$ 1$ º; art. 63). Tais garantias e requisitos não teriam sido observados, já que os atos censórios foram efetivados de maneira violenta e sem qualquer documento formal que os autorizasse.

O TFR sustentou a validade da censura nos três casos. No primeiro, referente ao jornal "EX”, o Ministro Jarbas Nobre, relator do caso, sustentou o seu voto no conceito de "homem médio", definindo-o como um meio termo entre o puritano e o liberal, isto é, "aquele que encontra encantamento ou deleite num trabalho que, inclusive, traga material lascivo, textos escabrosos, mas que no seu todo, contém matéria de cunho social ou artístico que de modo compensatório, oferece um resultado útil ou positivo" (BRASIL, TFR, 1976, p. 270).

Assim, de acordo com esse raciocínio, poderia ser admitido algum grau de conteúdo "lascivo", desde que este fosse "compensado" com algum conteúdo de teor instrutivo, cultural ou artístico. Tal "compensação"

passagens através de memorial recebido. E, confesso a V. Exa., Sr. Presidente, embora sendo um pecador que ainda não conseguiu redimir-se de certos pecados, fiquei estarrecido" (BRASIL, TFR, 1973, p. 62-64). 
inexistiria no caso da publicação objeto de censura, razão pela qual o relator, acompanhado por todos os demais Ministros, votou pela denegação da segurança. Confira-se a ementa do acórdão:

Mandado de Segurança. Presta-se a exame de matéria de fato que fira direito de alguém, desde que demonstrado por prova preconstituída. Seu conhecimento. Edição extraordinária de mensário - "EX", apreendida à alegação de afrontosa à moral e aos bons costumes. Apurado que a edição apreendida nada contém de artístico, científico, educacional ou literário, e que narra história sem conteúdo aproveitável, e faz quase idolatria de um viciado, como homem médio, isto é, comum ou ordinário, nem puritano, erudito ou liberal e nem, opostamente, pecador por vontade deliberada, libidinoso ou extravagante, não me sinto com liberdade, nem em condições de afirmar que o mensário apreendido não infringe a moral e os bons costumes. Segurança denegada (BRASIL, TFR, 1976, p. 257).

Posição similar foi adotada no caso do jornal "Jerusalém", no qual, por unanimidade, o TFR entendeu que o jornal continha publicações discriminatórias. A título de exemplo, o Ministro Carlos Madeira, relator do caso, analisou o conteúdo de duas reportagens - intituladas, respectivamente, "Não esqueceremos" e "Israel: ideologia do ódio e doutrina do terror" - que conteriam acusações contra os israelenses, reforçadas pelas cartas enviadas por leitores em solidariedade aos povos árabes. Com base nesses pressupostos, o Ministro assim concluiu o seu raciocínio:

Ora, essa insuflação de ódio entre dois segmentos de nossa população, choca-se não só com as nossas necessidades sociais, mas com a tradição de convivência pacífica de raças, que está na base de nossa formação e de nossa cultura. Há interesses não só do Estado, mas da sociedade brasileira, em que as divergências e as disputas entre as nações, por mais acirradas que se travem lá fora, sejam minimizadas e absorvidas no nosso modo de vida, de forma a amortecer ódios e preconceitos. A apreensão do jornal, portanto, é exercício de poder de polícia, na medida em que busca preservar, na vida de relação dos cidadãos, as regras de boa conduta e bom convívio, que são necessárias para evitar conflito de direitos e garantir a cada um o gozo ininterrupto de seu próprio direito [...] (BRASIL, TFR, 1983a, p. 188).

Argumentos similares foram considerados no julgamento da apreensão do diário "Luta, o Jornal do Povo", tendo a Corte se limitado a reconhecer a competência do Ministro da Justiça para determinar a apreensão do periódico. No entanto, o julgamento não foi unânime. Entre os dissidentes, o Ministro Carlos Velloso argumentou que os atos de apreensão de livros e impressos eram inconstitucionais, já que incompatíveis com a liberdade de manifestação do pensamento. Seguindo a interpretação de Pontes de Miranda, sustentou que tal prática repressiva não se amoldava às exceções previstas na $E C$ n no $01 / 1969$, norma que não submetia a publicação de livros e periódicos à prévia licença estatal.

Para o Ministro, a regra prevista na parte final do $₫ 8^{\circ}$ do art. 153 da Constituição de 1969, que estatuía não ser tolerável "a propaganda de guerra, de subversão da ordem ou de preconceitos de religião, de raça ou de classe, e as publicações e exteriorizações contrárias à moral e aos bons costumes", não poderia ser interpretada de modo a tornar inócua a garantia da livre manifestação do pensamento, prevista na parte inicial do mesmo dispositivo.

Em suma, de acordo com essa leitura, a análise sobre eventual afronta à moralidade pública ou às demais 
hipóteses dispostas no texto constitucional somente poderia ser realizada a posteriori e, mesmo assim, desde que observado o devido processo legal. Em suas palavras:

Então, para que possa ser iniciado o devido processo legal contra aquele que teria abusado do direito, far-se-á a apreensão de exemplares do jornal, ou do livro, a fim de servirem de corpo de delito. Admito que, dependendo da intensidade do abuso, poder-se-ia pensar até na apreensão de toda a edição do jornal, ou do livro. Essa apreensão, entretanto, somente poderia ser admitida numa ação cautelar, perante o Poder Judiciário, ou como medida preparatória de uma ação, ou como medida incidente. Admitir que edições inteiras de jornais possam ser apreendidas por ato de uma autoridade administrativa, o Ministro de Estado da Justiça, não se coaduna com a Constituição, pois representaria chancelar o Judiciário um ato de arbítrio. [...] as garantias de direito individual devem ser interpretadas com largueza e não restritivamente, porque gozar das liberdades públicas, num Estado de Direito, num Estado democrático, constitucional, é a regra. O contrário é a exceção. É claro que, num Estado que não de direito, que não democrático, gozar das liberdades públicas é a exceção. Mas nós pretendemos viver num Estado democrático, constitucional, num Estado cuja Constituição não seja, simplesmente, uma folha de papel (BRASIL, TFR, 1983b, p. 160 e 164).

Como se pode observar, o voto dissidente do Ministro Carlos Velloso propunha uma releitura da EC no 01/1969, baseada na atribuição de algum grau de preponderância aos direitos individuais. Estes - tal como no caso da liberdade de expressão - somente poderiam ser objeto de limitação estatal em hipóteses específicas, as quais, além de serem interpretadas de forma restritiva, deveriam observar o devido processo legal.

Não obstante os argumentos apresentados pelas partes e os votos dissidentes, os acórdãos do TFR - que consideraram legal a apreensão de livros e periódicos por ordem do Ministro da Justiça - reforçaram as competências das autoridades encarregadas da censura, legitimando a repressão e afastando qualquer interpretação protetiva dos direitos e garantias fundamentais. Essa tendência seria reforçada em outros casos, conforme veremos a seguir. ${ }^{11}$

\section{A censura legitimada}

A concepção autoritária e paternalista que sustentava a repressão às expressões culturais não foi inventada ex nihilo pelo regime militar. Como já referido, uma das principais normas utilizadas pela censura era o Decreto no 20.493, de 1946, promulgado muito antes do golpe de 1964. Esse aproveitamento de normas existentes para fins de legalização da repressão constitui uma das peculiaridades do regime militar brasileiro, conforme argumenta Anthony Pereira:

Uma inspeção mais meticulosa dos regimes brasileiro e chileno revela que eles não inventaram a legalidade da segurança nacional a partir do zero, mas, ao contrário, apropriaram-se de instituições, leis e organizações estatais autoritárias existentes, usando-as

\footnotetext{
${ }^{11}$ Vale registrar que atos de apreensão de periódicos também foram determinados pelo Ministro da Justiça com base na Lei de Segurança Nacional. A posição do TFR nestes casos também foi no sentido de considerar legítimos os atos de repressão. Ver os julgados proferidos nos Mandados de Seguranç̧a no 84.024, de 01/03/1979; 85.942, de 05/04/1979; 89.649 e 90.069, ambos de 16/10/1980; e 100.949, de 30/06/1983.
} 
para os próprios fins. No Brasil, houve mais empréstimos e menos inovações que no Chile, mas, em ambos os casos, as lideranças do regime forjaram um consenso a respeito de uma nova legalidade autoritária que mesclava elementos antigos e novos (PEREIRA, 2010, p. 181).

No âmbito específico da censura, o aproveitamento de normas antigas refletia, também, uma tradicional concepção autoritária e paternalista em torno do papel repressor do Estado sobre as expressões culturais e os meios de comunicação. De fato, como afirma Anne-Marie Smith, nunca houve no Brasil um "período de ouro" das liberdades de expressão e de imprensa:

Em primeiro lugar, temos a questão da memória institucional e do momentum. A experiência mostrava que o Estado interferia na imprensa, era assim que as coisas se passavam. Dessa forma, não foi um fato novo nem sequer surpreendente que o novo governo começasse a usurpar a liberdade de imprensa. Desde a época colonial, passando pelo Estado Novo e pelos anos de populismo imediatamente anteriores ao golpe, a imprensa podia esperar do Estado alguma interferência e tentativas de controle. [...] A liberdade de imprensa não podia ser reclamada com base numa herança reconhecida e compartilhada. [...] Conquanto tenha havido muitos aspectos novos na relação entre imprensa e Estado no período de 1964-85, houve também uma continuação significativa de padrões herdados do passado. Esse legado foi um ponto de partida, constituindo um dos fatores no estabelecimento de parâmetros para a relação entre imprensa e Estado nos anos do regime militar (SMITH, 2000, p. 30-31).

O fato é que havia um legado autoritário, o qual foi apropriado pelo regime militar, permitindo que a repressão fosse concebida como um instrumento necessário e próprio da atuação estatal em defesa da moralidade pública. Dito de outro modo, a história legitimava a censura e sustentava a normalidade da imposição de restrições de ordem coletiva sobre o exercício da liberdade de expressão, sempre conforme padrões definidos pelas autoridades públicas.

Foi, justamente, evocando esse tipo de argumento, que o TFR considerou legítima a censura sobre a peça “O Abat-jour Lilás”, de Plínio Marcos, que retratava a exploração de três prostitutas por um cafetão. Segundo o Ministro Márcio Ribeiro, relator da ação, a censura ao teatro era admitida no Brasil desde o Império e não poderia ser diferente, dada a "imoralidade” corriqueira na dramaturgia. Destacando a diminuição no rigor da repressão ao longo do tempo, o Ministro afirmou:

Segundo Temístocles Brandão Cavalcanti (Tratado de Direito Administrativo, V, 385), a censura teatral está na tradição de nosso direito, pois vinha sendo exercida muito antes das atuais ressalvas constitucionais. [...] no Rio de Janeiro, o Aviso no 123, de 1829, expedido em nome do Imperador [...] ordenava ao Administrador do Teatro S. Pedro de Alcântara que fizesse examinar previamente as peças pelo Desembargador-Intendente. [...] A nossa legislação, daí por diante, talvez com menor rigor, pelo menos no emprego de meios coercitivos, mas, diuturnamente, exigiu a censura prévia [...]. Os impetrantes declaram-se partidários da plena liberdade ou da censura exercida pelo próprio povo, mas essa opinião está contra a Constituição e as leis, inclusive a própria lei penal. Justamente devido a sua vinculação ao problema da moralidade pública, a censura teatral nunca pôde ser suprimida (BRASIL, TFR, 1975, p. 182-183).

Complementando o seu raciocínio, o Ministro defendeu que as decisões administrativas relativas à censura poderiam ser exercidas com plena discricionariedade, admitindo-se a correção judicial apenas "em casos 
extremos em que se revelasse, prima facie, o seu despropósito ou desarrazoamento" (BRASIL, TFR, 1975, p. 184). Esse entendimento foi expresso, também, na ementa do acórdão:

[...] O direito constitucional brasileiro considera compatível a liberdade de pensamento com a restrição prévia ou a censura de peça teatral. Da falta de conceito legal ou doutrinário preciso do que é pornográfico, obsceno ou contrário à moral e aos bons costumes, decorre ampla margem de discricionariedade às autoridades administrativas e, consequentemente, apenas nos casos extremos, de evidente erro do ato de censura, poderá ser feita sua revisão pelo Judiciário (BRASIL, TFR, 1975, p. 179).

Vale registrar o voto dissidente proferido pelo Ministro Jarbas Nobre. Para ele, a peça apresentava uma mensagem sadia, que em nada o impressionava ou escandalizava. A sua linguagem era compreensível, posto que compatível com o ambiente (um prostíbulo) no qual se passava a encenação. Esta teria por objetivo mostrar a "parte triste do mundo" e, assim, serviria a ensinar aos jovens os seus riscos e perigos. Por tal razão, a peça não afrontaria a moral e os bons costumes, merecendo, ademais, tratamento similar ao conferido pela censura à peça "Navalha na Carne", que apesar de ser do mesmo autor e narrar ambiente semelhante ao descrito em "Abat-jour Lilás”, fora liberada pelo Ministério da Justiça (BRASIL, TFR, 1975, p. 186-187).

Argumentação similar foi considerada pelo tribunal no caso da censura à peça "Calabar: o elogio da traição", de autoria de Chico Buarque e Ruy Guerra (BRASIL, TFR, 1974). O texto da peça havia sido liberado, porém, antes da realização do ensaio geral - que também deveria ser objeto de avaliação pela censura - a DCDP reviu sua posição, passando a proibir a apresentação da peça em todo o território nacional.

Para tanto, se baseou no disposto no art. 41, g, do Decreto n 20.493/1946, que autorizava a proibição de qualquer representação teatral que ferisse a dignidade ou o interesse nacional. A justificativa era a de que a peça distorcia fatos históricos ao conferir papel de herói ao traidor Domingos Fernandes Calabar, comerciante que, por ocasião da segunda invasão dos holandeses no Brasil, no século XVII, passou a colaborar com estes, traindo a Coroa Portuguesa. ${ }^{12}$

O autor da ação argumentou que a justificativa legal adotada pela DCDP era irregular, uma vez que, à época da invasão holandesa, o Brasil não existia como nação independente. Por isso, não havia qualquer interesse nacional em jogo no episódio. Uma vez que a fundamentação do ato não encontrava respaldo fático e legal, concluiu o impetrante, caberia ao judiciário declarar a sua nulidade, liberando a representação da peça.

O tribunal entendeu, por maioria, que o ato impugnado não configurava abuso de poder, já que calcado em farta motivação, a qual, dado se basear na análise de complexos fatos históricos, não caberia ser reavaliada pelo TFR, pelo menos não no âmbito do mandado de segurança, ação que não comporta instrução probatória.

\footnotetext{
${ }^{12}$ A seguinte fala da personagem Bárbara permite compreender bem o tom da peça (citado no acórdão, BRASIL, TFR, 1974, p. 109): "um dia este país há de ser independente dos holandeses, dos espanhóis, portugueses... Um dia todos os países poderão ser independentes, seja lá do que for. Mas isso requer muito traidor. Muito Calabar. E não basta enforcar, retalhar, picar... Calabar não morre, Anna. Calabar é cobra de vidro. E o povo jura que cobra de vidro é uma espécie de lagarto que quando se corta em dois, três mil pedaços, facilmente se refaz".
} 
Mais uma vez, o Ministro Jarbas Nobre apresentou voto dissidente, ao destacar a existência de corrente histórica que vê em Calabar uma figura heroica, que teria preferido o domínio dos holandeses em detrimento dos portugueses:

A obra de Chico Buarque de Holanda, 'Calabar, o Elogio da Traição', segue este segundo grupo de opinião. Encarando a peça teatral como obra de arte, as distorções são perfeitamente admissíveis. [...] Aceito, em princípio, os dois conceitos, e admito que os propugnadores das duas ideias opostas externem a sua convicção (BRASIL, TFR, 1974, p. 115).

Por fim, o Ministro entendeu que não se configurou o pressuposto indicado na motivação do ato contrariedade ao interesse nacional - visto que, conforme alegado pelo impetrante, no momento histórico em que se passava a peça, o Brasil não havia ainda se constituído como nação.

Por sua vez, no caso da censura à música "Rimas Sádicas", 13 de Juca Chaves, o Ministro José Cândido, relator da ação, entendeu que, de fato, a canção atentava contra a moral e os bons costumes. E que, dado estar repleta de palavras inconvenientes e ofensivas, deveria ter a sua veiculação proibida no rádio e na televisão, veículos em relação aos quais a atuação da censura deveria ser mais rígida quando em comparação com outros meios de expressão cultural. Ao agir assim, o Estado protegeria a sociedade brasileira e, em particular, as crianças e os jovens, evitando que estes fossem submetidos a influências negativas:

[...] não seria tolerável, por mais livre que fosse a nossa compreensão, que a censura permitisse a violação dos princípios da moral pública que preservam a ordem e a boa convivência social. [...] a agressão total ao pudor público, no que ele representa de decência média da sociedade e dos bons costumes, não pode ser aceita. Há de se compreender que o Rádio e a Televisão se transformaram nos mais eficientes veículos de comunicação social, pela liberdade com que ingressam nos lares e nos ambientes mais fechados. Por isso, sobre eles deve recair a maior parcela de vigilância do censor (BRASIL, TFR, 1981, p. 125-126).

O único voto divergente foi o do Ministro Américo Luz, que se posicionou a favor do impetrante, levando em conta o argumento de que a censura havia liberado músicas - de autoria de artistas como Roberto Carlos e Rita Lee - que continham palavras similares, conforme havia sido comprovado nos autos.

Concluindo o quadro das decisões que legitimaram a censura, vale mencionar o caso do filme Stallone Cobra, objeto de diversos cortes determinados pelas autoridades competentes. O relator do acórdão proferido pelo TFR, Ministro Lauro Leitão, afirmou que a censura se justificava diante da banalidade da violência mostrada no filme, em que "o 'mocinho' psicopata, travestido de justiceiro, sente a volúpia doentia de matar" (BRASIL, TFR, 1986, p. 393).

Nesse sentido, a intervenção do Estado constituiria uma medida necessária para conter a escalada da violência no país. A relação direta entre a exibição do filme e o incentivo à realização de atos de violência poderia,

\footnotetext{
${ }^{13}$ Para melhor compreensão do caso, transcrevo parte da letra da música: "depressa abre esta porta/ com teu cheiro de lua/ querote nua/ neste abraço louco/ meu corpo dar-te em troco/ compor sem mais receios/ um hino pros teus seios, pouco a pouco/ [...] procuro-te encontrada/ pois vim driblando os astros/ deixando os rastros de um tesão sem pejo/ deitar o meu desejo/ nas tuas curvas mágicas/ com rimas sádicas/ rimas beijo com beijo/ tesão ou tara [...]” (BRASIL, TFR, 1981, p. 123).
} 
inclusive, ser comprovada, haja vista a ocorrência de "acontecimentos violentos" com pessoas que teriam assistido à película. Concebendo a violência como uma "epidemia", que se alastra rapidamente, o Ministro Lauro Leitão classificou a atuação do tribunal como um ato em "defesa do organismo social", uma contribuição para que a sociedade brasileira pudesse dar um "basta à praga de filmes de violência que nos estão sendo impingidos pelas televisões e pelos cinemas" (BRASIL, TFR, 1986, p. 394). E, por fim, concluiu se valendo de uma justificativa central para a censura, qual seja, a vulnerabilidade peculiar do povo brasileiro: "convicto estou de que essa maciça propaganda tem realimentado a criminalidade, uma vez que o nosso povo, mais talvez que outros, se submete gostosamente às mensagens, diretas ou subliminares, que ouve e vê a todo momento" (BRASIL, TFR, 1986, p. $395) \cdot{ }^{14}$

Os Ministros que apresentaram votos dissidentes, como Carlos Velloso e Eduardo Ribeiro, entenderam que não estavam presentes, no caso, os requisitos para a concessão da suspensão de segurança. Tais requisitos como lesão à ordem e à segurança públicas - deveriam ser interpretados restritivamente, não cabendo ao tribunal, neste tipo de demanda, adentrar ao mérito da questão.

\section{A revisão da jurisprudência}

Em meados da década de 1980, o país vivia um momento de transição, no qual eram nítidos o ocaso do regime militar e os rumos democráticos que iriam guiar o país no futuro. Os Atos Institucionais haviam sido revogados, a anistia fora aprovada, a campanha das Diretas Já tomava as ruas e já se discutia a realização de uma Assembleia Constituinte.

Não obstante, o processo de mudança se impunha de cima para baixo, por meio de uma distensão lenta, gradual e segura. Por isso, o "entulho autoritário" não havia sido completamente eliminado, as elites e os militares mantinham sob controle as principais decisões políticas e a censura permanecia ainda muito atuante enquanto mecanismo de repressão às dissidências. ${ }^{15}$ Como bem sintetiza Daniel Aarão Reis, "no período de transição jánão havia ditadura, mas ainda não existia uma democracia" (REIS, 2014, p. 125).

Nesse contexto, amoldando-se aos novos tempos, o TFR passou a rever os precedentes que legitimavam

\footnotetext{
${ }^{14}$ A tese da vulnerabilidade peculiar do povo brasileiro "simples e ignorante" é encontrada em momentos históricos distintos como justificativa a amparar a censura, conforme destaca Smith (2000, p. 22): "ao ordenar o confisco do Correio Braziliense em 1809, por exemplo, a corte ressaltava as críticas do jornal ao governo, assim como sua 'malignidade e falsidade política que poderiam enganar o povo simples e ignorante’. A proteção dos vulneráveis - principalmente os vulneráveis em decorrência de sua simplicidade - volta a ocorrer repetidamente na história brasileira como justificativa da coerção de um subgrupo pelo Estado".

${ }^{15}$ Segundo Beatriz Kushnir, "as elites brasileiras souberam se moldar e se adaptar ao processo de abertura para continuarem no poder". A autora ressalta, ainda, que, mesmo após a posse do presidente Sarney, entre 1985 e 1987, a repressão às expressões culturais continuou a pleno vapor: "[...] foram 261 letras de músicas cortadas e 25 terminantemente vetadas. Novelas e textos teatrais também tiveram cenas suprimidas, e o conjunto de censores, que era de 150 técnicos, aumentou para 220, já que houve um concurso de admissão em 1986" (KUSHNIR, 2004, p. 138; 147). Para mais detalhes sobre o período da transição democrática, cf. SILVA (2012).
} 
a censura de diversões públicas. Em diversos julgados relativos à censura de filmes - muitos dos quais, filmes pornográficos - o tribunal impôs limites à atuação das autoridades administrativas, reconhecendo a autonomia dos espectadores e a prevalência dos direitos individuais sobre a proteção da ordem e da moralidade pública.

Assim é que, em uma decisão paradigmática, o TFR determinou a liberação dos filmes "A mulher e... La Bete" e "Contos Imorais", considerando ilegal e abusiva a proibição imposta pelo Ministro da Justiça (BRASIL, TFR, 1982a; 1982b). Esta autoridade havia revisto, de ofício, decisão favorável às produtoras dos filmes, tomada pelo Conselho Superior de Censura - CSC, órgão colegiado que contava com representantes do governo e da sociedade civil, conforme previsto na Lei no $5.536 / 1968$.

O entendimento majoritário se baseou no argumento de que ao tribunal caberia analisar a legalidade do ato, independentemente do conteúdo do filme. E, sob essa ótica, não havia dúvida de que a lei não conferia ao Ministro da Justiça poder para rever de ofício decisões do Conselho Superior de Censura. A interposição de recurso, "pelo interessado", seria uma formalidade essencial, decorrente da própria literalidade do art. 18 da Lei no $5.536 / 1968$, que não fora observada nos casos em questão. ${ }^{16}$

Dos votos vencidos, cabe destacar a posição do Ministro Jesus Costa Lima, similar em ambos os acórdãos. O Ministro apontou a relevância da proteção à moralidade e aos bons costumes para a sociedade brasileira, destacando que se tratava de princípio constitucional autoaplicável, o que legitimaria a decisão do Ministro da Justiça. Ademais, a este a lei conferiu o poder hierárquico e os correlatos poderes de supervisão ministerial e de avocação, os quais teriam sido utilizados - como dito, com o objetivo de assegurar a prevalência da própria Constituição - dentro dos limites da legislação então em vigor. Confira-se a seguinte passagem de seu voto:

Logo, para que a ordem jurídica fosse restabelecida com o respeito ao que a Constituição manda, ao Senhor Ministro da Justiça não se oferecia outra alternativa qual a de obstaculizar a propaganda da imoralidade, na plena consciência de que num país onde não se respeita a moral ou os bons costumes, degrada-se o homem, fenecem as instituições, periga a integridade nacional, caminha-se para a derrocada. A Constituição existe para ser cumprida, para reger a vida da nação, para constituir a ordem jurídica e não para ficar nas estantes. Aquilo que a Carta Magna considera intolerável, o CSC - o Poder Público - não pode tolerar, sob pena de ofender a Constituição (BRASIL, TFR, 1982a, p. 95).

Embora sob a roupagem de uma questão mais técnica, o fato é que as decisões em tela conferiram legitimidade à atuação do Conselho Superior de Censura. No mesmo passo, distanciando-se dos precedentes firmados no caso de apreensão de periódicos com base na Lei de Imprensa, as decisões tiveram por efeito restringir os poderes repressivos que a ordem jurídica conferia ao Ministro da Justiça, limitando o seu campo de

\footnotetext{
${ }^{16}$ Art. 18. Da decisão não unânime do Conselho Superior de Censura caberá recurso ao Ministro da Justiça, interposto dentro de 15 (quinze) dias, a contar da ciência do ato, pelo interessado, e solucionado no prazo de 30 (trinta) dias.
} 
atuação discricionária. ${ }^{17}$ Por fim, como demonstra o voto vencido acima transcrito, o tribunal deixou de lado fortes argumentos de mérito, que, em tese, encontravam respaldo na própria Constituição, em particular no que concerne à defesa da moral e dos bons costumes frente à liberdade de expressão.

Na mesma linha, o TFR determinou a liberação de filme publicitário da marca de lingerie Du Loren, sustentando que o ato de censura detinha natureza vinculada, e que, ainda que sempre reste alguma margem de discricionariedade, o administrador deve se circunscrever aos limites fixados em lei e apontar os motivos que amparam a sua decisão, o que não ocorrera no caso. $\mathrm{O}$ acórdão foi assim ementado:

ADMINISTRATIVO. CENSURA DE FILME PUBLICITÁRIO. ATO ADMINISTRATIVO. CONTROLE JURISDiCIONAL. Possibilidade de o Poder Judiciário examinar os motivos determinantes do ato impugnado, que é vinculado, por excelência, sem que, no controle jurisdicional, invada o campo da conveniência e da oportunidade de sua prática. Remessa oficial improvida (BRASIL, TFR, 1987).

Como se pode observar, neste caso, ao admitir o crivo judicial sobre os motivos determinantes do ato administrativo, o tribunal se afastou do entendimento que conferia ampla margem de discricionariedade aos agentes responsáveis pela repressão às expressões culturais. Doravante, o judiciário poderia, com maior intensidade, adentrar à análise do ato, sem que isso implicasse uma interferência ilegítima no campo das opções de conveniência e oportunidade próprias do administrador público.

Não se tratava, portanto, de uma revisão judicial calcada em um "erro evidente", como exigiam os parâmetros fixados nos julgados anteriores, mas, sim, de uma nova e mais abrangente orientação judicial, que se amparava em um dos princípios fundamentais do Estado de direito, que é o da limitação ao poder e a correlata necessidade de submissão dos atos administrativos à lei.

Pode-se dizer, ainda, que, neste acórdão, o TFR resgatou, de forma ampliada, o princípio que havia orientado o precedente firmado nos casos dos filmes "A mulher e... La Bete" e "Contos Imorais". Na ocasião, como visto, o tribunal impôs limites à atuação discricionária do Ministro da Justiça ao ratificar o poder decisório do Conselho Superior de Censura. A diferença é que, no presente caso, as restrições legais às prerrogativas decisórias das autoridades da censura autorizariam a intervenção do poder judiciário no que concerne ao próprio mérito do

\footnotetext{
${ }^{17}$ Também impondo limites à atuação do Poder Executivo e fortalecendo o Conselho Superior de Censura foi a decisão proferida no MS no 97.992, julgado em 16/06/1983, no qual o sindicato dos artistas e técnicos em espetáculos de diversões públicas questionava a exclusão de seu representante da composição do Conselho, conforme havia sido efetuada pelo Decreto $n^{\circ}$ 87.325/1982 e pela Portaria no 519/1982 do Ministro da Justiça. A ação foi julgada procedente pelo TFR. A ementa é a seguinte: "ADMINISTRATIVO. CENSURA. CONSELHO SUPERIOR. COMPOSIÇÃO. RESERVA LEGAL. REPRESENTAÇÃO DE CATEGORIAS PROFISSIONAIS (ARTISTAS E TÉCNICOS EM ESPETÁCULOS DE DIVERSÕES PÚBLICAS). Estabelecida a composição do Conselho Superior de Censura através de lei, não pode ato de hierarquia inferior introduzir alteração, excluindo representação expressamente prevista. A natureza da matéria e a evolução histórica da política censória conduzem à convicção de estar o assunto sujeito ao princípio da reserva legal. O CSC não pode ser identificado como órgão integrante da estrutura ministerial, de sorte a subordinar-se à recomendação contida no art. 81, item V, da Constituição Federal. A exclusão do representante dos Artistas e Técnicos em Espetáculos de Diversões Públicas do elenco previsto no artigo 16, da Lei nº 5.536, de 1968, não podia ser objeto de disciplina regulamentar. Preliminares de ilegitimidade ativa e passiva rejeitadas. Segurança concedida" (BRASIL, TFR, 1983c, p. 43).
} 
ato administrativo questionado.

Em outra decisão relevante, proferida poucos meses antes da promulgação da Constituição de 1988, o TFR concedeu autorização para uma produtora exibir filmes eróticos nos cinemas nacionais, desde que restritos a maiores de dezoito anos e com avisos expressos de que as películas continham "cenas de sexo explícito" (BRASIL, TFR, 1988a).

O voto do Relator, Ministro Sebastião Reis, limitou-se a transcrever e ratificar a sentença de primeiro grau. Nesta, o magistrado argumentou que a decisão de ir ao teatro ou ao cinema se insere no âmbito da escolha e da responsabilidade de cada indivíduo. Em suas palavras,

Basta, simplesmente, que a pessoa tenha convicção do que deseja, e condições legais (maioridade) para cumprir a sua determinação. É questão pessoal, que cada um do povo deve assumir, sem que a censura tenha necessidade de dispender suas energias, de certa forma infrutíferas para esse mister, até porque, o que se assiste na via pública, nas praias e nas boates, não fica muito aquém da realidade em que nos colocamos, de certa época para cá. Tenho para mim que o primordial é a conscientização do indivíduo; a sua escolha deve ser respeitada; o direito de publicar, escrever, filmar e representar, é sagrado, assumindo, cada um, a parcela de responsabilidade do que pretendeu fazer ou está fazendo (BRASIL, TFR, 1988a, p. 03).

Constata-se aqui mais uma inflexão na jurisprudência do TFR, o que pode se creditar à transição democrática, àquela altura já em ritmo acentuado, em especial, com as discussões travadas na Assembleia Constituinte. Dessa forma, o paternalismo estatal e a correspondente presunção de vulnerabilidade do povo brasileiro, vistos com frequência em decisões anteriores, deram lugar a uma nascente concepção liberal, baseada na necessidade de proteção da liberdade e da autonomia individuais frente à intervenção do Estado. Esta deveria se circunscrever aos momentos e às circunstâncias em que, de fato, haveria risco para a coletividade ou para grupos de indivíduos vulneráveis, como as crianças e os adolescentes.

Dessa forma, ao princípio da limitação ao poder, o tribunal acrescentou o princípio da autonomia individual, afastando a necessidade de intervenção estatal para a proteção dos cidadãos. Embora com alguma resistência dentro da Corte, que se veria em um julgado posterior, ${ }^{18} \mathrm{o}$ acórdão trouxe à tona uma nova leitura das relações entre Estado e indivíduo, com nítido acento para a liberdade individual, e isso antes de entrar em vigor a nova Constituição ou de serem revogadas as principais normas que regiam a censura.

O mesmo princípio seria reforçado em outra decisão, na qual o TFR afastou a caracterização do crime de desobediência, ao conceder habeas corpus a estudante que havia assistido, em recinto universitário, ao filme "Je

\footnotetext{
${ }^{18}$ Dois meses após essa decisão, a Terceira Turma do TFR, em caso bem similar, sustentou a validade da censura sobre filmes pornográficos: "CONSTITUCIONAL. CENSURA. FILMES PORNOGRÁFICOS. ATOS ADMINISTRATIVOS MOTIVADOS. A liberdade de expressão de pensamento encontra limitações no nosso ordenamento constitucional, em se tratando de diversões e espetáculos públicos. Não é, também, tolerada, quando diz com a 'propaganda de guerra, de subversão da ordem ou de preconceitos de religião, de raça ou de classe' com 'as publicações de exteriorizações contrárias à moral e aos bons costumes' (art. 153, $\mathbb{S} 8^{\circ}, \mathrm{CF}$ ). Filmes pornográficos, cuja tônica, segundo a avaliação dos órgãos censórios, é a apologia de perversão sexual e a prática do sexo pelo sexo. Incidência de vedação constitucional, por ofensa à moral e aos bons costumes. Atos
} 
vous salue, Marie”, de Jean-Luc Godard. Segundo a autoridade policial, a desobediência teria se caracterizado, uma vez que a exibição do filme fora proibida, pelo Diretor da Divisão de Censura, em todo o território nacional.

Seguindo decisão similar da justiça de primeira instância, o TFR firmou entendimento de que a censura de diversões públicas não alcançava a exibição de filmes em recintos fechados, tal como no caso das universidades. Aliado a isso, seria parte da própria atividade de pesquisa e discussão acadêmicas o acesso e a análise crítica de bens culturais. Com base nesses argumentos, a decisão foi assim ementada:

PENAL. DESOBEDIÊNCIA. EXIBIÇÃO CINEMATOGRÁFICA. Descaracterização. A proibição da censura dirige-se tão-somente à exibição em casas de diversões ou espetáculos públicos, não abrangendo recintos fechados e inacessíveis ao público, pois tal valeria odiosa tutela de consciências (BRASIL, TFR, 1988c, p. 157).

Dessa maneira, o acórdão mitigou a censura ao polêmico filme "Je Vous Salue, Marie", excluindo as universidades de sua esfera de imposição. O fato é que, mais uma vez, a liberdade e a autonomia individuais prevaleceram sobre o paternalismo e a "tutela estatal das consciências", conforme expressão utilizada na ementa.

\section{CONCLUSÃO}

Diante de todo o exposto, pode-se retomar a pergunta problema inicial, conforme apresentada na Introdução, a respeito do posicionamento adotado pelos tribunais superiores no julgamento de casos envolvendo a censura de espetáculos e diversões públicas no decorrer da ditadura militar.

Para responder a essa questão, é importante considerar que, ao longo dos anos, a repressão estatal sobre a liberdade de expressão no Brasil, notadamente no âmbito das expressões culturais, constituiu-se como parte integrante de uma tradição autoritária, centrada na imposição de limites muito estreitos sobre a autonomia dos cidadãos. Nesse contexto, a defesa da moralidade pública se afirmou como um mecanismo essencial de proteção da coletividade e de seus valores fundamentais, assegurando a harmonia entre os seus diversos integrantes ou, ainda, impedindo uma suposta desagregação de ordem moral.

No período da ditadura militar, a censura de diversões públicas se insere e dá continuidade a esse legado autoritário, cuja face mais visível se revela na legislação editada antes do golpe de 1964, logo apropriada pelo regime ditatorial. Daí a sensação de "normalidade" que parece conduzir boa parte dos votos e decisões citados neste artigo. E é compreensível que assim seja, pois pouco havia de novo na repressão às expressões culturais, conforme bem destacado pelo Ministro Márcio Ribeiro, do TFR, ao lembrar, no voto proferido no caso da peça "O Abat-jour Lilás", que, no Brasil, a censura sobre as expressões culturais foi imposta desde o Império. Diante de tal tradição autoritária, percebida e tomada como justificativa pelas próprias autoridades judiciárias, a pergunta, de fácil resposta, permanecia a mesma: como permitir que determinadas ideias e palavras, todas "evidentemente"

administrativos plenamente motivados e fundamentados. Apelação provida" (BRASIL, TFR, 1988b, p. 131). 
imorais, fossem ditas em público, expostas nos palcos ou transmitidas para o recinto do lar da família brasileira?

As instituições estatais, certamente, não poderiam permanecer inertes. Algo precisava ser feito, sob pena, diriam os mais afoitos, de perecimento da nação. Parte relevante da sustentação a esse ímpeto de controle sobre as diversões públicas veio dos tribunais superiores e da teoria subjacente às decisões judiciais que legitimaram a censura, fundada em três elementos centrais. Primeiro, a teoria clássica da discricionariedade administrativa, que conferia ampla margem decisória às autoridades da censura, afastando, na prática, qualquer possibilidade de controle judicial sobre o mérito de seus atos. Segundo, uma concepção forte de paternalismo, de acordo com a qual, dada a sua peculiar vulnerabilidade, os cidadãos deveriam ser tutelados e protegidos pelo Estado. Por fim, em um plano mais abstrato, o conceito de autoridade, demandando o respeito incondicional à tradição, à hierarquia social e às ordens estatais.

Por outro lado, essa concepção não se afirmou sem rupturas ou questionamentos. Mesmo no período mais duro da repressão, autores, editoras e produtoras defenderam a liberdade de expressão e votos divergentes foram proferidos acolhendo seus argumentos. Nesse sentido, vale mencionar a posição do Ministro Adauto Cardoso, que chegou a renunciar ao cargo após a decisão do STF no caso da Reclamação no 849, impetrada em face do Decreto-lei no 1.077/1970; e os votos divergentes do Ministro Jarbas Nobre, do TFR, apresentados nos casos das peças de teatro "O Abat-jour Lilás" e "Calabar: o elogio da traição".

Posteriormente, já no período da transição democrática, essas posições deixaram de ser minoritárias, passando a dominar a jurisprudência do Tribunal Federal de Recursos. Emergiu, assim, uma nascente concepção liberal e democrática de liberdade de expressão, amparada no princípio da limitação ao poder estatal e na autonomia dos cidadãos. Foi o que se verificou na análise de casos envolvendo a limitação dos poderes repressivos do Ministro da Justiça, a legitimação da atuação do Conselho Superior de Censura e a liberação de filmes eróticos.

É importante destacar, por fim, a atualidade do confronto entre autoridade e liberdade, que esteve no centro das discussões judiciais no período da ditadura militar. De fato, nos dias de hoje, em muitas situações que envolvem a imposição de limites à liberdade de expressão, é possível identificar dilemas similares em torno da legitimidade da regulação estatal e de sua relação com a autonomia dos cidadãos e com a afirmação de um espaço público aberto e plural. O desafio posto é o de se afastar dos princípios que sustentaram a censura de diversões públicas e o de desenvolver, de forma mais articulada, os princípios da limitação ao poder e da autonomia dos cidadãos, base de qualquer concepção democrática de liberdade de expressão. 


\title{
CENSORSHIP IN THE DOCK: SUPERIOR COURTS DECISIONS IN THE MILITARY DICTATORSHIP
}

\begin{abstract}
The article analyzes the major decisions handed down by the Supreme Court and the Federal Court of Appeals in cases dealing with censorship of public entertainment, as imposed during the Brazilian military dictatorship (1964-1985). The paper argues that censorship was legitimated by courts decisions, as they assigned wide discretion to administrative authorities to control cultural expression, always with the purpose of protecting public morals and citizens themselves. That position - supported by three core elements: the classical theory of administrative discretion, paternalism and the notion of authority - was overruled in the mid-1980s, during the transition to democracy, when the courts began to endorse the principle of citizen autonomy and the imposition of legal limits on administrative authorities.
\end{abstract}

Keywords: Censorship; Freedom of Expression; Military Dictatorship; Authoritarianism; Democracy.

\section{REFERENCIAS}

ARENDT, Hannah. Entre o passado e o futuro. 7a ed. São Paulo: Perspectiva, 2011.

BINENBOJM, Gustavo. Uma teoria do direito administrativo: direitos fundamentais, democracia e constitucionalização. $2^{\mathrm{a}}$ ed. Rio de Janeiro: Renovar, 2008.

BRASIL. Decreto no 20.493, de 24 de Janeiro de 1946. Aprova o Regulamento do Serviço de Censura de Diversões Públicas do Departamento Federal de Segurança Pública. Diário Oficial da União, 29 jan. 1946.

Constituição (1937). Diário Oficial da União, 10 nov. 1937.

Constituição (1967). Diário Oficial da União, 24 jan. 1967.

Decreto-lei no 1077, de 26 de janeiro de 1970. Dispõe sobre a execução do artigo 153, $\$ 8^{\circ}$, parte final, da Constituição da República Federativa do Brasil. Diário Oficial da União, 26 jan. 1970.

Emenda Constitucional no 1 , de 17 de outubro de 1969. Edita o novo texto da Constituição Federal de 24 de janeiro de 1967. Diário Oficial da União, 20 out.1969.

Lei $n^{\circ}$ 5.250, de 9 de fevereiro de 1967. Regula a liberdade de manifestação de pensamento e de informação. Diário Oficial da União, 10 fev. 1967.

Lei no 5.536, de 21 de novembro de 1968. Dispõe sobre a censura de obras teatrais e cinematográficas, cria o Conselho Superior de Censura, e dá outras providências. Diário Oficial da União, 22 nov. 1968.

Supremo Tribunal Federal. Recurso em Mandado de Segurança no 18.534/SP. Editora Abril Ltda e Juiz de Direito da Vara de Menores da Capital. Relator: Ministro Aliomar Baleeiro. Julgado em 01/10/1968.

Supremo Tribunal Federal. Reclamação no 849/DF. Movimento Democrático Brasileiro e ProcuradorGeral da República. Relator: Ministro Adalício Nogueira. Julgado em 10/03/1971. In.: Revista Trimestral de Jurisprudência, n 59, fev. 1972, p. 333-350.

Tribunal Federal de Recursos. Mandado de Segurança no 73.636/DF. Editora Civilização Brasileira e Ministro de Estado da Justiça. Relator: Ministro Moacir Catunda. Julgado em 06/12/1973. In: Revista do Tribunal Federal de Recursos, no 46, abr./jun. 1975, p. 58-64.

Tribunal Federal de Recursos. Mandado de Segurança no 74.626/DF. Francisco Buarque de Holanda e Diretor-Geral do Departamento de Polícia Federal. Relator: Ministro José Neri da Silveira. Julgado em 16/05/1974. In: Revista do Tribunal Federal de Recursos, nº 48, out./dez. 1975, p. 106-118. 
Tribunal Federal de Recursos. Mandado de Segurança no 76.935/DF. Plínio Marcos de Barros e Ministro de Estado da Justiça. Relator: Ministro Márcio Ribeiro. Julgado em 30/10/1975. In: Revista do Tribunal Federal de Recursos, no 52, out./ dez. 1976, p. 179-191.

Tribunal Federal de Recursos. Mandado de Segurança no 77.536/DF. EX-Editora Ltda. e Ministro de Estado da Justiça. Relator: Ministro Jarbas Nobre. Julgado em 20/05/1976.

Tribunal Federal de Recursos. Mandado de Segurança no 94.746/DF. Jurandyr C. Chaves e Ministro de Estado da Justiça. Relator: Ministro José Cândido. Julgado em 18/12/1981.

Tribunal Federal de Recursos. Mandado de Segurança no 95.060/DF. Artenova Filmes Ltda. e Ministro de Estado da Justiça. Relator: Ministro Wilson Gonçalves. Julgado em 27/05/1982a.

Tribunal Federal de Recursos. Mandado de Segurança n 96.356/DF. Artenova Filmes Ltda e Ministro de Estado da Justiça. Relator: Ministro José Cândido. Julgado em 24/06/1982b.

Tribunal Federal de Recursos. Mandado de Segurança no 99.312/DF. Mohamad Said Mourad e Ministro de Estado da Justiça. Relator: Ministro Carlos Madeira. Julgado em 24/03/1983a.

Tribunal Federal de Recursos. Mandado de Segurança no 99.602/DF. Edigrajo - Editora e Gráfica Jornalística Ltda. e Ministro de Estado da Justiça. Relator: Ministro Sebastião Alves dos Reis. Julgado em 19/05/1983b.

Tribunal Federal de Recursos. Mandado de Segurança no 97.992/DF. Sindicato dos Artistas e Técnicos em Espetáculos de Diversões no Estado de São Paulo e Ministro da Justiça. Relator: Ministro William Patterson. Julgado em 16/06/1983c.

Tribunal Federal de Recursos. Agravo Regimental na Suspensão de Segurança no 5.818/DF. Warner Bros. Inc. e Diretor da Divisão de Censura de Diversões Públicas da Polícia Federal. Relator: Ministro Lauro Leitão. Julgado em 18/12/1986. In.: Revista do Tribunal Federal de Recursos, nº 147, jul. 1987, p. 391-399.

Tribunal Federal de Recursos. Remessa Ex Officio n 104.776/SP. Propaganda Estrutural S/A e União Federal. Relator: Ministro Carlos Thibau. Julgado em 31/03/1987.

Tribunal Federal de Recursos. Apelação Cível no 115.190/RJ. União Federal e Martes Filmes S/A. Relator: Ministro Sebastião Reis. Julgado em 23/03/1988a.

Tribunal Federal de Recursos. Apelação Cível no 118.251/RJ. União Federal e Cinematográfica F. J. Lucas Netto Ltda e outros. Relator: Ministro Miguel Ferrante. Julgado em 25/05/1988b.

Tribunal Federal de Recursos. Recurso de Habeas Corpus no 7.487/SP. Ruben Tedeschi Rodrigues e Justiça Pública. Relator: Ministro Edson Vidigal. Julgado em 30/09/1988c.

BUZAID, Alfredo. Em defesa da moral e dos bons costumes. Brasília: Ministério da Justiça, 1970.

GRINBERG, Lucia. Adauto Lúcio Cardoso, da UDN à ARENA. In: KUSHNIR, Beatriz (org.). Perfis cruzados: trajetórias e militância política no Brasil. Rio de Janeiro: Imago, 2002, p. 245-259.

KUSHNIR, Beatriz. Cães de guarda: jornalistas e censores, do AI-5 à Constituição de 1988. São Paulo: Boitempo, 2004.

MEIRELLES, Hely Lopes. Direito administrativo brasileiro. 4a ed. São Paulo: Revista dos Tribunais, 1976.

MIRANDA, Pontes de. Comentários à Constituição de 1967: com a Emenda no 1, de 1969. Tomo V. 2a ed. São Paulo: Revista dos Tribunais, 1973.

O ESTADO DE SÃO PAULO. Censura leva crise ao STF; Adauto sai. São Paulo, 11/03/1971, p. 1. Disponível em: http:/ /acervo.estadao.com.br/pagina/\#!/19710311-29425-nac-0001-999-1-not. Acesso: 17/07/2012.

PEREIRA, Anthony W. Ditadura e repressão: o autoritarismo e o estado de direito no Brasil, no Chile e na Argentina. São Paulo: Paze Terra, 2010. 
REIS, Daniel Aarão. Ditadura e democracia no Brasil. Rio de Janeiro: Zahar, 2014.

SILVA, Francisco Carlos Teixeira. Crise da ditadura militar e o processo de abertura política no Brasil, 1974-1985. In: FERREIRA, Jorge; DELGADO, Lucilia (org.). O Brasil Republicano. O tempo da ditadura: regime militar e movimentos sociais em fins do século XX. São Paulo: Civilização Brasileira, 2012, p. 243-282.

SMITH, Anne-Marie. Um acordo forçado: o consentimento da imprensa à censura no Brasil. Rio de Janeiro: FGV, 2000 .

VIEIRA, Nayara da Silva. Entre o imoral e o subversivo: a Divisão de Censura de Diversões Públicas (DCDP) no Regime Militar (1968-1979). Dissertação (mestrado), Departamento de História, Universidade de Brasília, 2010.

Trabalho enviado em 01 de julho de 2016.

Aceito em 09 de outubro de 2016. 